Check for updates

Cite this: RSC Adv., 2018, 8, 24276

\title{
Facile metal-free reduction-based synthesis of pristine and cation-doped conductive mayenite $\uparrow$
}

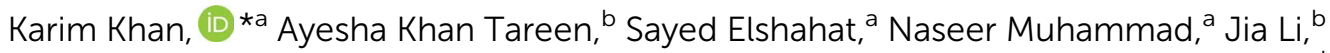
Israa Aboodd, ${ }^{a}$ Luigi Bibbò, ${ }^{a}$ Ashish Yadav, ${ }^{a}$ Rizwan Ur Rehman Sagar, ${ }^{c}$ Usman Khan ${ }^{d}$ and Zhengbiao Ouyang (iD) *a

In the present study we synthesized conductive nanoscale $\left[\mathrm{Ca}_{24} \mathrm{Al}_{28} \mathrm{O}_{64}\right]^{4+}\left(4 \mathrm{e}^{-}\right)$(hereafter denoted as $\mathrm{C}_{12} \mathrm{~A}_{7}: \mathrm{e}^{-}$) material, and reduced graphene oxide ( $\mathrm{rGO}$ ) was produced, which was unexpected; graphene oxide was removed after melting the sample. The conductivity of $\mathrm{C}_{12} \mathrm{~A}_{7}: \mathrm{e}^{-}$composites synthesized at $1550{ }^{\circ} \mathrm{C}$ was $1.25 \mathrm{~S} \mathrm{~cm}^{-1}$, and the electron concentration was $5.5 \times 10^{19} \mathrm{~cm}^{-3}$. The estimated BET specific surface area of the highly conductive sample was $20 \mathrm{~m}^{2} \mathrm{~g}^{-1}$. Pristine $\mathrm{C}_{12} \mathrm{~A}_{7}: \mathrm{e}^{-}$electride was obtained by melting the composite powder, but the nano size of $\mathrm{C}_{12} \mathrm{~A}_{7}: \mathrm{e}^{-}$particles could not be preserved; the value of conductivity was $\sim 28 \mathrm{~S} \mathrm{~cm}^{-1}$, electron concentration was $\sim 1.9 \times 10^{21} \mathrm{~cm}^{-3}$, and mass density was $93 \%$. For $C_{12} A_{7-x} V_{x}: e^{-}$, where $x=0.25$ to 1 , the conductivity improved to a maximum value of $40 \mathrm{~S} \mathrm{~cm}^{-1}$, and the electron density improved to $\sim 2.2 \times 10^{21} \mathrm{~cm}^{-3}$; this enhancement in conductivity was also proposed by a theoretical study but lacked any associated experimental support.

Received 31st March 2018 Accepted 1st June 2018

DOI: $10.1039 / \mathrm{c} 8 \mathrm{ra02790k}$

rsc.li/rsc-advances of obtaining electron gas can be found, and the conductivity from insulating nature till superconductive nature can be changed without loss of the fundamental cage framework structure. ${ }^{6,7}$ The important applications of the ubiquitous ceramic-based transparent conducting inorganic electride $\mathrm{C}_{12} \mathrm{~A}_{7}: \mathrm{e}^{-}$make this novel, cheap, and environmentally friendly material more attractive. Since the discovery of the first roomtemperature stable inorganic electride $\mathrm{C}_{12} \mathrm{~A}_{7}: \mathrm{e}^{-}$, this material has attracted much attention due to its unique properties such as high electron concentration $\left(\sim 2.3 \times 10^{21} \mathrm{~cm}^{-3}\right)$ and low work function $(\mathrm{WF} \sim 2.4 \mathrm{eV}){ }^{8} \mathrm{C}_{12} \mathrm{~A}_{7}: \mathrm{e}^{-}$has been utilized as a catalyst for ammonia synthesis/decomposition, ${ }^{9-11}$ activation and splitting of carbon dioxide ${ }^{8}$ oxide ion conductivity, ${ }^{12-14}$ circuit of wires and electrodes,$^{15}$ pinacol coupling reaction in aqueous media, ${ }^{16}$ and reforming of bio-oil ${ }^{17}$ it has also been used as a prototype electronic conductor and chemical reducing agent for solvated electrons in alkali metal-ammonia solutions, ${ }^{7}$ in oxide fuel cells, as an oxidation catalyst or oxygen gas sensor, ${ }^{4}$ as a cathode material in fluorescent lamp, ${ }^{18}$ as a short-channel nano-wire transistor, ${ }^{19}$ electron emitter, and electron-injection layer in OLEDs, as a secondary electron emitter in a plasma display panel, and as a chemical reductant. ${ }^{20}$ Continuous improvements in its properties and applications are under way, but complexity of the previous synthesis processes of $\mathrm{C}_{12} \mathrm{~A}_{7}: \mathrm{e}^{-}$ has motivated many researchers towards developing direct simple synthesis routes because the previous methods were associated with high energy consumption, long synthesis time, lower surface area and most importantly, unsuitability for cation doping in $\mathrm{C}_{12} \mathrm{~A}_{7}: \mathrm{e}^{-}$. Another important consideration is surface cage protection for which $\mathrm{Ar}^{+}$sputtering with annealing
College of Electronic Science and Technology, THz Technical Research Center, Key Laboratory of Optoctronics Devices and Systems of Ministry of Education Guangdong Province, Shenzhen University, Shenzhen 518060, China. E-mail: bouyang@szu.edu.cn; karim_khan_niazi@yahoo.com

${ }^{b}$ Ningbo Institute of Material Technology and Engineering, Chinese Academy of Sciences, Ningbo, 315201, P. R. China

${ }^{c}$ College of Materials Science and Engineering \& College of Optoelectronic Engineering, Shenzhen University, 518060, P. R. China

${ }^{d}$ Low Dimensional Materials and Devices Laboratory, Tsinghua-Berkeley Shenzhen Institute, Tsinghua University Shenzhen, 518055, P. R. China

$\dagger$ Electronic supplementary information (ESI) available. See DOI: $10.1039 / \mathrm{c} 8 \mathrm{ra} 02790 \mathrm{k}$ 
at $1050{ }^{\circ} \mathrm{C}$ for $<20 \mathrm{~min}$ (ref. 20) or ripped-thermal annealing (RTA) at $950{ }^{\circ} \mathrm{C}$ for $80 \mathrm{~s}$ are used, ${ }^{21}$ which improves surface conduction to a point but decreases the surface area.

The most important and interesting aspect of this research is the availability of access free cages in $\mathrm{C}_{12} \mathrm{~A}_{7}$ unit cell, which increases the possibility of the storage of extra "extrinsic free oxygen" in the available empty cages in its unit cell. ${ }^{22}$ Hence, after reduction in doping in $\mathrm{C}_{12} \mathrm{~A}_{7}: \mathrm{e}^{-}$, the extra electron, rather than that of the intrinsic electride $\left(\sim 2.3 \times 10^{23} \mathrm{~cm}^{-3}\right)$, can be accommodated up to a maximum theoretical value of $\sim 6 \times 10^{23} \mathrm{~cm}^{-3}$ and hence, the corresponding conductivity increases. Theoretical and experimental studies have been conducted for some of the cation substitutions in $\mathrm{C}_{12} \mathrm{~A}_{7}$. Briefly, previously used conventional synthesis methods involving all types of doping caused a decrease in the electronic conductivity except Si-substitution, where the conductivity increased from 0.15 to $0.61 \mathrm{~S} \mathrm{~cm}^{-1}$ for $x=0$ to $4 .{ }^{23}$ Therefore, this paper with respect to $\mathrm{C}_{12} \mathrm{~A}_{7}: \mathrm{e}^{-}$electride is directed towards two challenges: designing and exploring a single stepbased scalable facile approach to synthesize $\mathrm{C}_{12} \mathrm{~A}_{7}: \mathrm{e}^{-}$electride nano-powders and boosting the electrical properties through doping with suitable valence cations.

\section{Experimental strategy}

\section{Characterization methods}

Possible chemical reactions during sintering were characterized using thermo gravimetric/differential thermal analyses (TG/ DTA; Diamond Pyrix, Perkin Elmer, USA). X-ray powder diffraction (XRD) analysis was performed using a Bruker AXS D8 Advanced diffractometer (USA) with $\mathrm{Cu} \mathrm{K} \alpha$ radiation source $(\lambda=$ $0.15406 \mathrm{~nm}, 40 \mathrm{kV}, 360 \mathrm{~mA})$. Electrical conductivity was measured using the four probe method. Brunauer-EmmettTeller (BET) specific surface areas and volume/width of the pores of the samples were characterized using an automatic specific surface area and pore physical adsorption analyzer (ASAP 2020, Micromeritic, USA) after heating the samples at $200{ }^{\circ} \mathrm{C}$ for 5 hours. A high resolution scanning electron microscope (HR-SEM, Hitachi-S4800, Japan) and a high resolution transmission electron microscope (HR-TEM, JEOL-2100, Japan) were used to study the microstructure and morphology of sintered powders. An X-ray photoelectron spectrometer (Thermo Scientific, VG Multilab 2000) was used for X-ray photoelectron spectroscopy (XPS) measurement with $\mathrm{Al} \mathrm{K} \alpha$ radiation $(h \nu=$ $1486.6 \mathrm{eV})$ under UHV $\left(1.33 \times 10^{-8} \mathrm{~Pa}\right)$. For wide and narrow scans, the energy resolutions were set to $0.5 \mathrm{eV}$ and $0.05 \mathrm{eV}$, respectively. The analyzer pass energy was set to $20 \mathrm{eV}$ for narrow scans. All peaks were calibrated by the carbon deposit $\mathrm{C}$ 1s binding energy at $284.8 \mathrm{eV}$. Finally, for the investigation and characterization of the structure of molecules and bonding of the graphitic materials, Raman spectroscopy was used. Raman spectra were obtained by excitation using a $532 \mathrm{~nm}$ air-cooled argon ion laser $(20 \mathrm{~mW})$.

\section{Synthesis approach}

Synthesis conditions and fabrication process strongly affect the final material properties. To synthesize $\mathrm{C}_{12} \mathrm{~A}_{7}: \mathrm{e}^{-}$via a modified sol-gel-based synthesis method without using citric acid (CA), analytical grade starting materials $\mathrm{Ca}\left(\mathrm{NO}_{3}\right)_{2} \cdot 4 \mathrm{H}_{2} \mathrm{O}$ and $\mathrm{Al}\left(\mathrm{NO}_{3}\right)_{3} \cdot 9 \mathrm{H}_{2} \mathrm{O}$ were purchased from Aladdin/Shanghai, China, and they were used without further purification. First, metal nitrates were weighed using a specific molecular ratio $\left(\mathrm{Ca}\left(\mathrm{NO}_{3}\right)_{2} \cdot 4 \mathrm{H}_{2} \mathrm{O}: \mathrm{Al}\left(\mathrm{NO}_{3}\right)_{3} \cdot 9 \mathrm{H}_{2} \mathrm{O}=12: 14\right)$ and then dissolved in ethylene glycol $\left(\mathrm{C}_{2} \mathrm{H}_{6} \mathrm{O}_{2}, \mathrm{EG}\right)$ at $60{ }^{\circ} \mathrm{C}$ to obtain a transparent solution. This solution was kept at about $100{ }^{\circ} \mathrm{C}$ for one hour to vaporize physically absorbed water and then, it was finally dried at $275{ }^{\circ} \mathrm{C}$ for 4 hours in an oven to vaporize extra EG and form the dried gel. The resulting yellowish dried foam-like gel was crushed into powder and further pulverized and heat-treated at $500{ }^{\circ} \mathrm{C}$ for $1 \mathrm{~h}$ in a nitrogen environment to decompose the metal nitrides. The product was again crushed into a fine powder and then divided into two parts: one part was pressed using an iso-static press system at $150 \mathrm{MPa}$ to obtain a pellet shape ( $\sim 7.5 \mathrm{~cm}$ diameter), and the other part was directly used to get conductive powder. Finally, the resultant powder and pellets were sintered in an alumina crucible under a nitrogen atmosphere with a heating rate of $4{ }^{\circ} \mathrm{C} \min ^{-1}$, and the temperatures were maintained at $850{ }^{\circ} \mathrm{C}, 1250{ }^{\circ} \mathrm{C}, 1350{ }^{\circ} \mathrm{C}$, and $1550{ }^{\circ} \mathrm{C}$ for $1 \mathrm{~h}$. In the case of doping, the same synthesis procedure was repeated, and sources of "V" and "Si" were added to the precursors separately, with molar ratios $x=0.25,0.50$, 0.75 , and 1.

\section{Results and discussion}

The synthesized $\mathrm{C}_{12} \mathrm{~A}_{7}: \mathrm{e}^{-}$sample was then used for an initial investigation into its crystalline nanoparticles and bulk form by employing different experimental conditions based on the synthetic pathways from precursors to final conductive powder.

\section{Thermo gravimetric and differential thermal (TG/DTA) analysis}

Under the guidance of the formation mechanism, the synthesized $\mathrm{C}_{12} \mathrm{~A}_{7}$ : $\mathrm{e}^{-}$powder is discussed in detail by using different experimental conditions based on the synthetic pathways from precursors to final conductive powder. Therefore, to know the basic physical and chemical changes in the material properties as a function of increasing temperature at a constant rate, TG/ DTA of the gel was performed. Fig. 1 shows the TG/DTA curves of the as-prepared precursor gel; the measurement was performed in a nitrogen environment from $30{ }^{\circ} \mathrm{C}$ to $1200{ }^{\circ} \mathrm{C}$. It was observed that there existed four major weight loss processes in this temperature range. The first weight loss was due to the removal of water in the gel system, which occurred at about $100{ }^{\circ} \mathrm{C}^{24}$ The second clear continuous weight loss of about $35 \%$ up to $450{ }^{\circ} \mathrm{C}$ corresponded to the changes from nitrates to oxides and/or from absorbed EG to carbon. The heat treatments of the gels at $500{ }^{\circ} \mathrm{C}$ yielded decomposed ash (AS), which contained carbon as well as hydroxyl carbonate, ${ }^{25}$ as confirmed by the color of AS. ${ }^{26,27}$ Third, two small endothermic peaks were observed in the range of $750-930{ }^{\circ} \mathrm{C}$ accompanied by further weight loss of about 5\%, as shown in the TG curve, suggesting complete decomposition of all meta-stable phases and the 


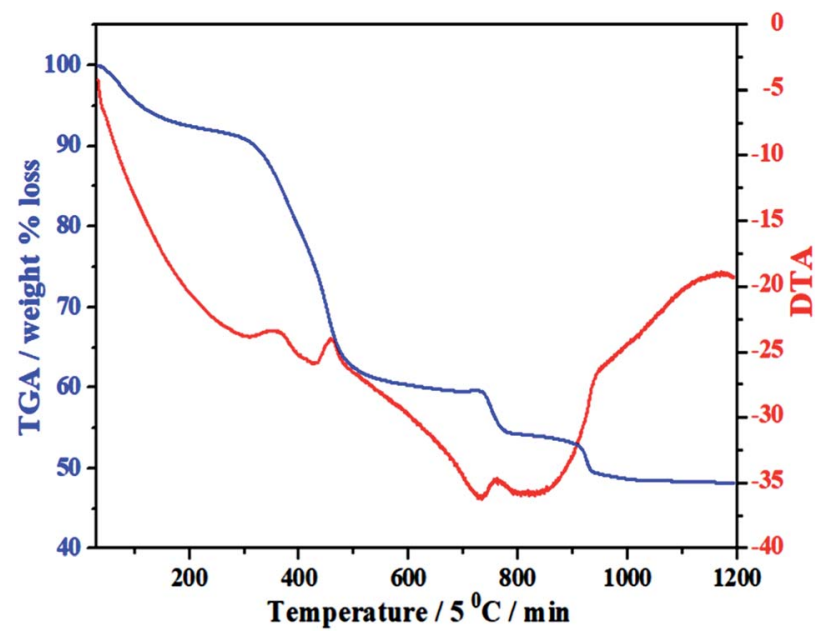

Fig. 1 TG/DTA of mixed-milled nitrates xerox-gel.

formation of $\mathrm{C}_{12} \mathrm{~A}_{7}$ crystalline phase ${ }^{26-28}$ the reduction process of $\mathrm{C}_{12} \mathrm{~A}_{7}$ also started in this temperature range. ${ }^{26-28}$ On the other hand, a small extent of this small weight loss may also be due to some water loss; water formation at such a high temperature was caused due to $\mathrm{OH}^{-}$and $\mathrm{O}^{-2}$ in cages. ${ }^{9}$

The important point during this heat treatment process is that a distinct exothermic peak at $750{ }^{\circ} \mathrm{C}$ was obtained, which indicated the oxidization of carbon from incomplete combustion of EG; ${ }^{25}$ this oxidization of free carbon maybe because of the oxygen present in cages. The non-conductive property of the sample heated at $\leq 750{ }^{\circ} \mathrm{C}$ was observed because no distinct reduction occurred even the existence of carbon in sample. The sample heat-treated above this temperature had a distinct value of conductivity, which further increased with the increasing synthesis temperature under the same condition of applied environment and time.

\section{X-ray powder diffraction (XRD) structural analysis}

Taking into account the above-mentioned TG/DTA variation trend, we selected different synthesis temperatures and studied XRD patterns of the synthesized $\mathrm{C}_{12} \mathrm{~A}_{7}: \mathrm{e}^{-}$phase. The gel was heat-treated at $500{ }^{\circ} \mathrm{C}$ for $1 \mathrm{~h}$ in a nitrogen environment, and it yielded dark-gray ash (AS), which was amorphous in nature and did not indicate any peaks of hydroxyl carbonate, hydroxyl and carbonate groups; it was also independent of decomposition either in a single step or in two steps. ${ }^{25}$ The $\mathrm{C}_{12} \mathrm{~A}_{7}: \mathrm{e}^{-}$phase identification and crystallinity, based on XRD results, illustrated that the crystalline phase of $\mathrm{C}_{12} \mathrm{~A}_{7}: \mathrm{e}^{-}$was observed first at about $1050{ }^{\circ} \mathrm{C}$ (Fig. 2). ${ }^{27}$ The samples treated at $1250{ }^{\circ} \mathrm{C}$ and $1550{ }^{\circ} \mathrm{C}$ showed well-resolved sharp peaks in the XRD pattern, which corresponded to the well-crystalline $\mathrm{C}_{12} \mathrm{~A}_{7}$ phase (JCPDS, CAS \# 48-1882).

The reduction treatment changed the sample color from yellow gel to a gray ash and finally to a dark-black crystalline $\mathrm{C}_{12} \mathrm{~A}_{7}: \mathrm{e}^{-}$single phase with increasing synthesis temperature for the same duration of treatment. Previously, it was reported that when the sample was heated to $1500{ }^{\circ} \mathrm{C}$ or higher than that, it

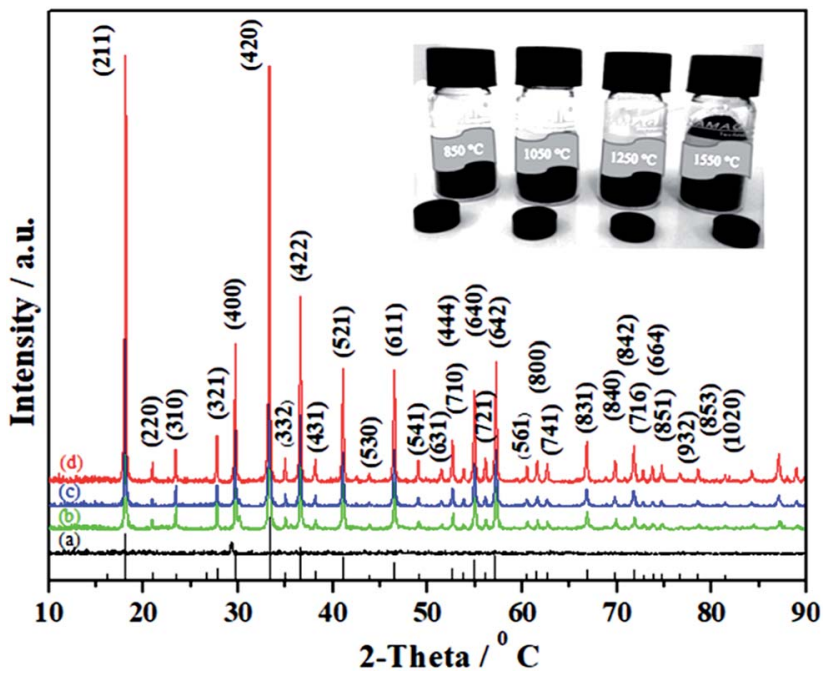

Fig. 2 Powder XRD patterns of as-synthesized samples at (a) $850^{\circ} \mathrm{C}$, (b) $1050^{\circ} \mathrm{C}$, (c) $1250^{\circ} \mathrm{C}$, and (d) $1550^{\circ} \mathrm{C}$. For comparison, the lines on the $x$-axis correspond to the peak positions for the pure $C_{12} A_{7}$.

decomposed to $\mathrm{CaO} \cdot \mathrm{Al}_{2} \mathrm{O}_{3}(\mathrm{CA})+3 \mathrm{CaO} \cdot \mathrm{Al}_{2} \mathrm{O}_{3}\left(\mathrm{C}_{3} \mathrm{~A}\right)$ because the $\mathrm{O}^{2-}$ ions in the framework tended to be removed at high temperatures, which led to the decomposition of $\mathrm{C}_{12} \mathrm{~A}_{7}$ phase into a $\mathrm{CA}+\mathrm{C}_{3} \mathrm{~A}$ mixture; however, this was not observed here because of the presence of $\mathrm{C}_{2}{ }^{2-}$ ions. ${ }^{29,30}$ To understand the detailed structure and chemistry of the powders, Raman spectroscopy was used to characterize the residual carbon in the system.

\section{Raman analysis}

Raman spectroscopy has historical importance in the investigation and characterization of molecular structure and bonding, especially of the graphitic materials. Fig. 3 shows the obtained Raman spectra of the highly conductive $\mathrm{C}_{12} \mathrm{~A}_{7}: \mathrm{e}^{-}$ composite heat-treated at $1550{ }^{\circ} \mathrm{C}$ and excited with a laser of wavelength $532 \mathrm{~nm}$. The highest intense G-band peak, assigned to $\mathrm{sp}^{2}$-hybridized carbon atoms, was observed at about $1578 \mathrm{~cm}^{-1}$ (G-mode), and another second intense 2D band peak was observed at $2684 \mathrm{~cm}^{-1}$ (2D-mode). It is believed that the intensity of the D-band peak is closely related to the defects (such as edges and ripples) present in graphene sheets, and this band was observed at about $1337 \mathrm{~cm}^{-1}$ (D-mode); ${ }^{31}$ this relatively low value of the $\mathrm{D}$ peak indicated less defects and good quality of the resulting rGO. ${ }^{32,33}$ Here, the $I_{\mathrm{D}} / I_{\mathrm{G}}$ ratio was about 0.26 , indicating some impurities and defects in the graphitized graphene structure, ${ }^{34}$ and this value was much lower than the typical value of $0.3-0.4$ for polycrystalline $\mathrm{N}$-doped graphene. ${ }^{35}$ However, here, we obtained a single, sharp 2D band peak for graphene. ${ }^{36}$

Raman bands located at $200-1000 \mathrm{~cm}^{-1}$ were obtained due to the lattice framework of $\mathrm{C}_{12} \mathrm{~A}_{7}$, which was composed of tetrahedrally coordinated $\mathrm{Al}^{3+}$ ions. The peak between 1137 and $1164 \mathrm{~cm}^{-1}$, which was assigned as the $\mathrm{O}_{2}{ }^{-}$stretching mode, was not observed in the sample, ${ }^{37}$ indicating the reduction of $\mathrm{C}_{12} \mathrm{~A}_{7}$ to $\mathrm{C}_{12} \mathrm{~A}_{7}: \mathrm{e}^{-}$. The band at $1128 \mathrm{~cm}^{-1}$ assigned to the stretching 


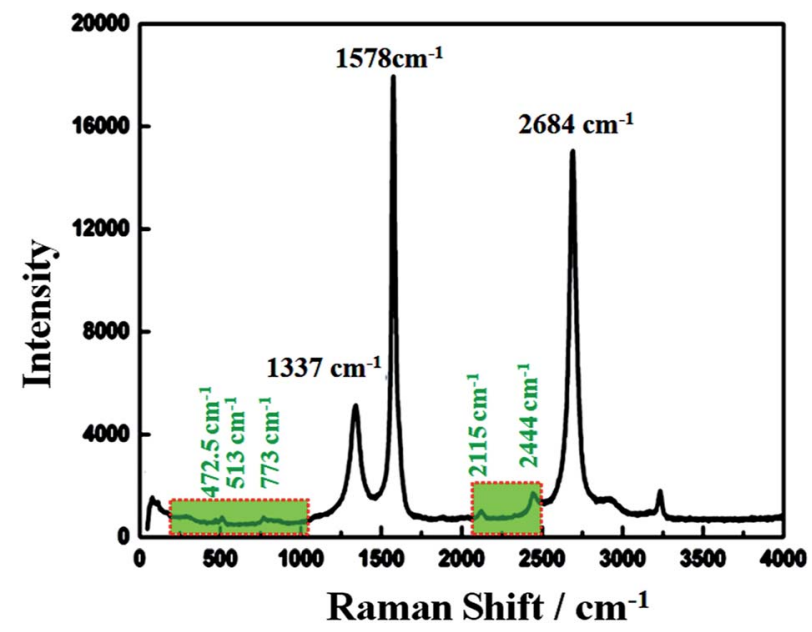

Fig. 3 Raman spectrum of $\mathrm{C}_{12} \mathrm{~A}_{7}: \mathrm{e}^{-}$composite.

mode of the extra $\mathrm{O}^{2-}$ ion present in the framework was not observed here. ${ }^{38}$ The band peaks positioned at $546 \mathrm{~cm}^{-1}$ and $521 \mathrm{~cm}^{-1}$ corresponded to the CA phase, whereas the typical band peaks of the $\mathrm{C}_{3} \mathrm{~A}$ phase observed at $756 \mathrm{~cm}^{-1}$ and $508 \mathrm{~cm}^{-1}$ were also not observed here, thereby confirming that there was no other phase formation. ${ }^{30}$ Therefore, the XRD patterns along with the Raman spectra showed that $\mathrm{C}_{12} \mathrm{~A}_{7}: \mathrm{e}^{-}$ pure phase, at all synthesis temperatures, whereas no decomposition to other phases of this family such as CA, pure C3A or mixed phases occurred. Therefore, the Raman spectra indicated the presence of the $\mathrm{C}_{12} \mathrm{~A}_{7}: \mathrm{e}^{-}$species and the presence of $\mathrm{rGO}$.

\section{SEM- and TEM-based morphological study}

The SEM analysis was conducted on the sample heated at $1550{ }^{\circ} \mathrm{C}$, and images were collected at different magnifications (Fig. 4). The micrographs show randomly shaped particles of nanosized dimensions, but it was found that graphene was coated on these particles. Fig. 4 also shows EDS-based elemental mapping of the $\mathrm{C}_{12} \mathrm{~A}_{7}: \mathrm{e}^{-}-\mathrm{rGO}$ composites. The element distribution maps revealed many interesting aspects. The intensity of each image is indicative of the signal intensity of each ion. In Fig. 4, Ca, $\mathrm{Al}, \mathrm{O}$ and $\mathrm{C}$ particles are shown by different colors on the distribution maps. The results confirmed the almost expected theoretical contents of $\mathrm{Ca}, \mathrm{O}$, and $\mathrm{Al}$ with extra $\mathrm{C}$ content in the final sample, supporting Raman and XRD results.

For further explanation, we conducted TEM of the $\mathrm{C}_{12} \mathrm{~A}_{7}: \mathrm{e}^{-}$ composite powder. The TEM images showed isolates and uniform $\mathrm{C}_{12} \mathrm{~A}_{7}: \mathrm{e}^{-}$nanosized particles with the average size of ca. $8-10 \mathrm{~nm}$, without the aggregated precipitates (Fig. 5(a)). In
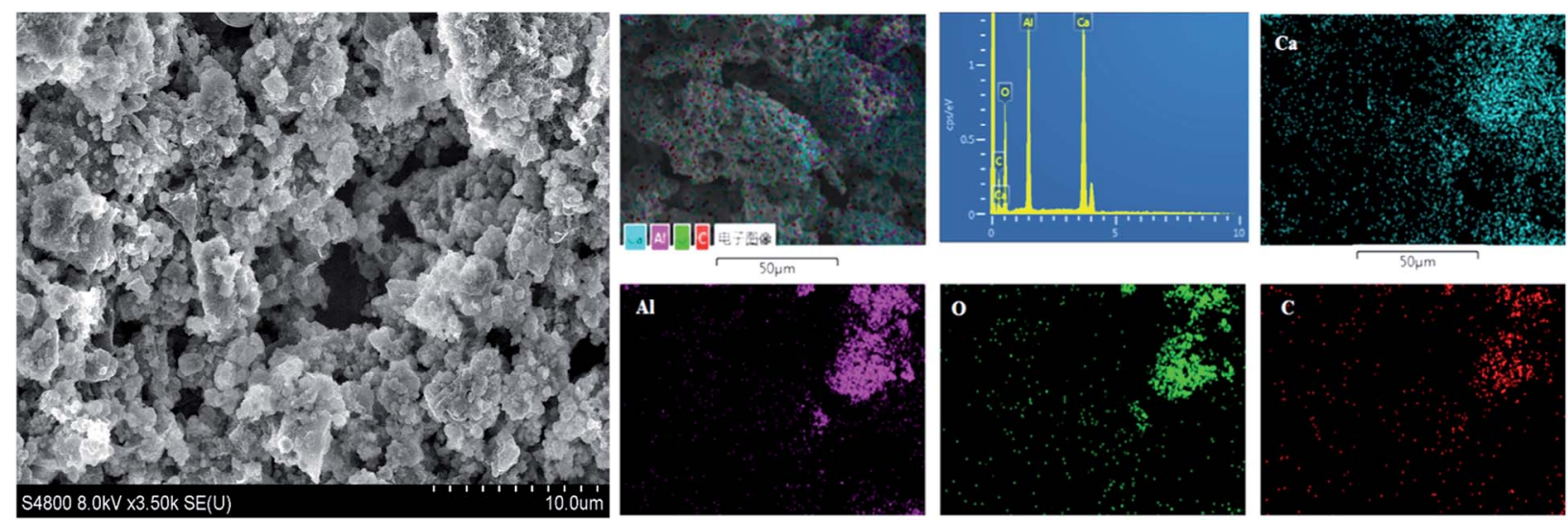

Fig. 4 SEM images and elemental mapping obtained by EDX for $\mathrm{C}_{12} \mathrm{~A}_{7}: \mathrm{e}^{-}$composites synthesized at $1550{ }^{\circ} \mathrm{C}$.
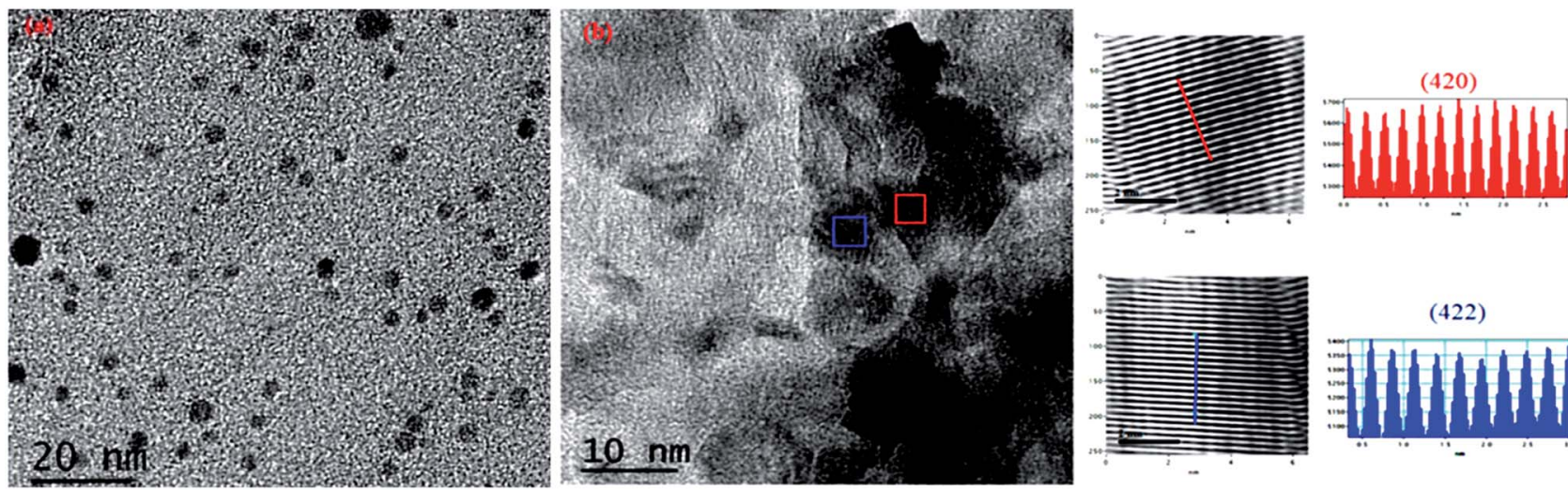

Fig. 5 TEM and HR-TEM images patterns of $C_{12} A_{7}: \mathrm{e}^{-}$composite synthesis at $1550{ }^{\circ} \mathrm{C}$ for 1 hour. 

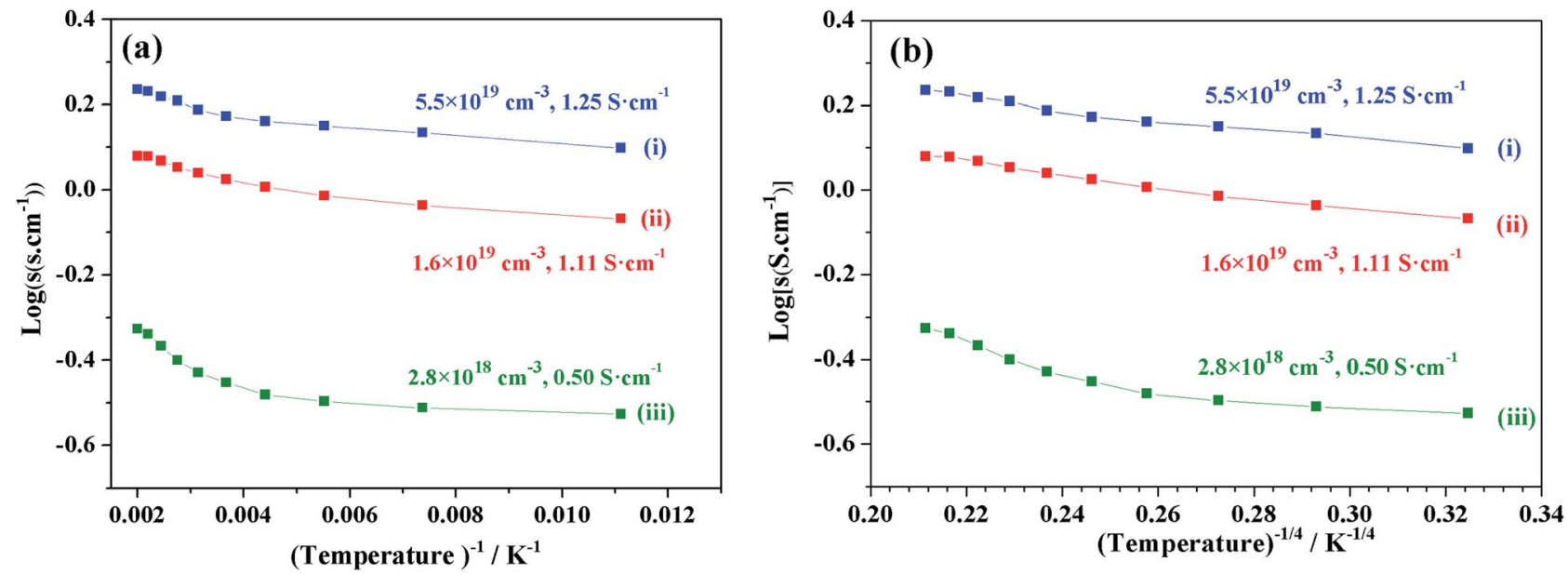

Fig. $6 \log (\sigma)$ vs. temperature $\left(\mathrm{T}^{-1}, \mathrm{~T}^{-4}\right)$ of sample synthesis at (i) $1550{ }^{\circ} \mathrm{C}$, (ii) $1250^{\circ} \mathrm{C}$, and (iii) $1050^{\circ} \mathrm{C}$.
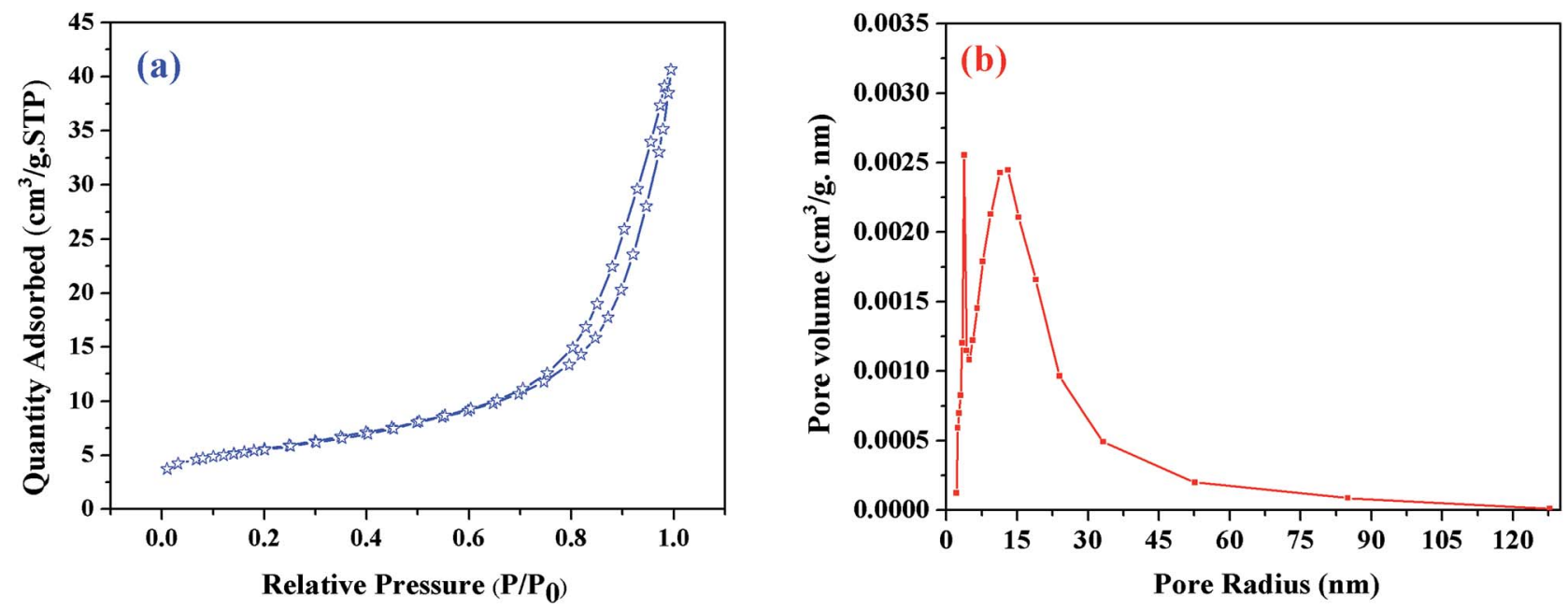

Fig. 7 (a) BJH pore size distributions, (b) $\mathrm{N}_{2}$ adsorption/desorption isotherms of $\mathrm{C}_{12} \mathrm{~A}_{7}$ : $\mathrm{e}^{-}$composite $\left(1550{ }^{\circ} \mathrm{C}, 1 \mathrm{~h}\right)$.

Fig. 5(b), the d-spacing values corresponded to the well-defined diffraction planes of the $\mathrm{C}_{12} \mathrm{~A}_{7}$ phase (JCPDS, CAS \# 48-1882).

\section{Electrical properties of $\mathrm{C}_{12} \mathrm{~A}_{7}: \mathrm{e}^{-}$composite}

We focused on the variation in conductivity-temperature characteristics; therefore, the gel was pressed into a pellet form, and it was heated in an $\mathrm{N}_{2}$ gas atmosphere for 1 hour at $500{ }^{\circ} \mathrm{C}$, $850{ }^{\circ} \mathrm{C}, 1050{ }^{\circ} \mathrm{C}, 1250{ }^{\circ} \mathrm{C}$, and $1550{ }^{\circ} \mathrm{C}$ (Fig. 6). The conductivity was measured using Pt electrodes in a 4-probe configuration, with variable temperatures ranging from $90 \mathrm{~K}$ to $500 \mathrm{~K}$ (Fig. 6). Samples heat-treated at temperatures below $850{ }^{\circ} \mathrm{C}$ also had no prominent conductivity. We tested the conductivity of samples synthesized at $1050{ }^{\circ} \mathrm{C}, 1250^{\circ} \mathrm{C}$, and $1550{ }^{\circ} \mathrm{C}$, where the electron concentrations of the samples were $2.8 \times 10^{18} \mathrm{~cm}^{-3}, 1.6 \times 10^{19}$ $\mathrm{cm}^{-3}$, and $5.5 \times 10^{19} \mathrm{~cm}^{-3}$ and the conductivities were about $0.5 \mathrm{~S} \mathrm{~cm}^{-1}, 1.11 \mathrm{~S} \mathrm{~cm}^{-1}$ and $1.25 \mathrm{~S} \mathrm{~cm}^{-1}$, respectively. At a synthesis temperature range of $900-1300{ }^{\circ} \mathrm{C}$, water uptake occurred, and it caused a decrease in conductivity. Therefore, an abrupt increase in conductivity at a temperature of about $1550{ }^{\circ} \mathrm{C}$ occurred. ${ }^{12,39}$

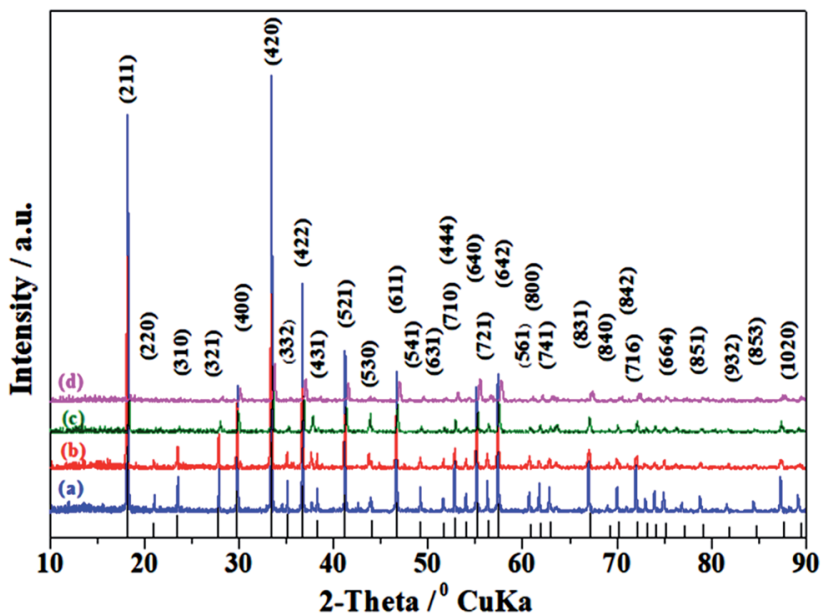

Fig. 8 XRD of $C_{12} A_{7-x} V_{x}: e^{-}$, where $x=$ (a) 1, (b) 0.75, (c) 0.50, (d) 0.25, heated at $1550{ }^{\circ} \mathrm{C}$ for $1 \mathrm{~h}$. The lines on the $x$-axis correspond to the peak positions for pure $\mathrm{C}_{12} \mathrm{~A}_{7}$. 

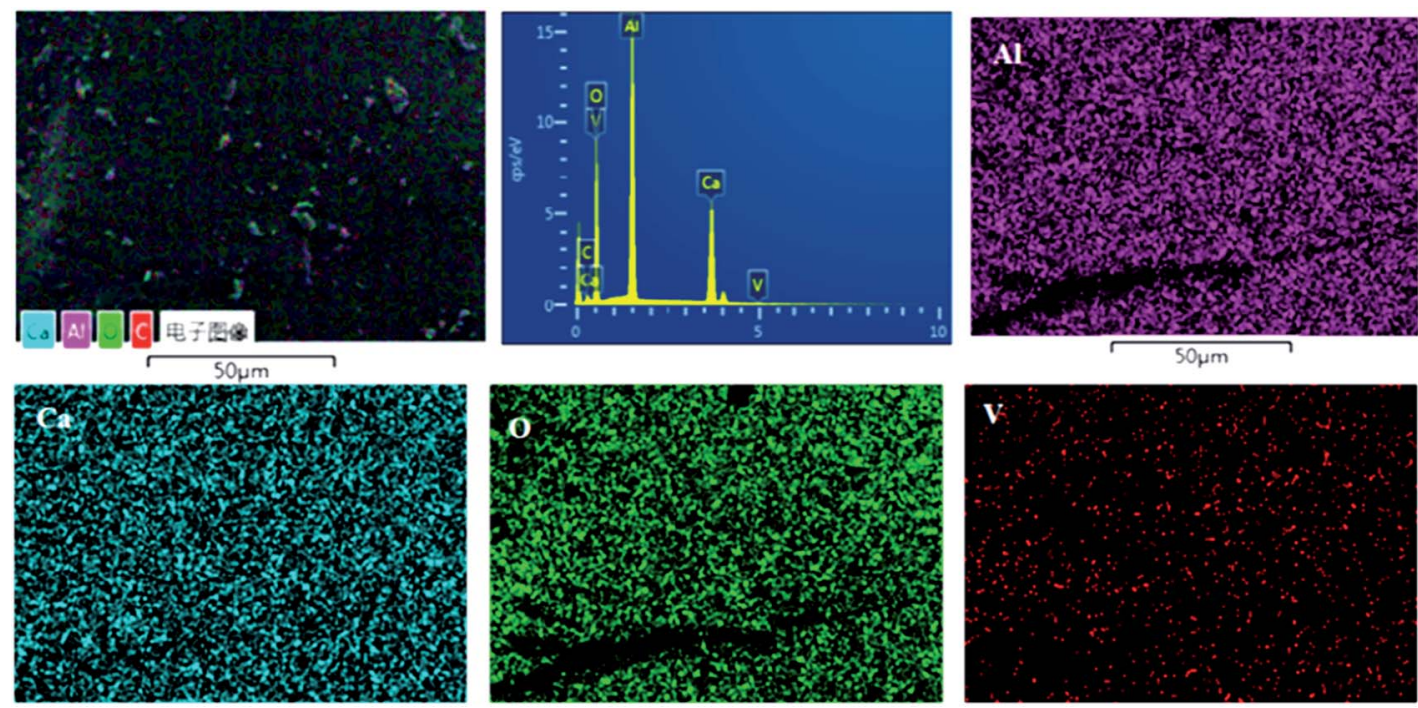

Fig. 9 Elemental mapping obtained by EDX for $C_{12} A_{7-x} V_{x}: e^{-}$, where $x=1$.

\section{BET-based specific surface area and pore size/volume measurement}

BET theory is based on the physical adsorption-desorption of gas molecules on a solid surface by which the specific surface area of that material is calculated. The estimated BET specific surface area of the resulting sample heat-treated at $1550{ }^{\circ} \mathrm{C}$ was about $20 \mathrm{~m}^{2} \mathrm{~g}^{-1}$; Fig. 7(a) shows its $\mathrm{N}_{2}$ adsorption-desorption profiles, where $P$ is the partial pressure of the adsorbate and $P_{\mathrm{o}}$ is the saturated vapor pressure of the adsorbent. According to the IUPAC classification, the $\mathrm{N}_{2}$ isotherm is a type-III isotherm, and the higher $\mathrm{N}_{2}$ adsorption confirmed the higher specific surface area of this sample. ${ }^{40}$ The pore size distribution was calculated using the BJH method (Fig. 7(b)). The results revealed that the $\mathrm{C}_{12} \mathrm{~A}_{7}: \mathrm{e}^{-}$composite showed a sharp peak at about $2.7 \mathrm{~nm}$, and another peak was observed at about $15 \mathrm{~nm}$, suggesting that the sample possessed almost uniform pore size distributions of about 2.7 and $15 \mathrm{~nm}$. This optimized sol-gel method is extremely valuable for the synthesis of $\mathrm{C}_{12} \mathrm{~A}_{7}: \mathrm{e}^{-}$ because the out-diffusion of the free oxygen ions from $\mathrm{C}_{12} \mathrm{~A}_{7}$ is not blocked in any way, and if the carbon layer completely covers the sample powder surface, this will further enhance the reduction process.

\section{V-doped $\mathrm{C}_{12} \mathrm{~A}_{7}: \mathrm{e}^{-}$}

The XRD patterns of $\mathrm{C}_{12} \mathrm{~A}_{7-x} \mathrm{~V}_{x}: \mathrm{e}^{-}$samples, where $x=0.25$ to 1 (hereafter, V-doped $\mathrm{C}_{12} \mathrm{~A}_{7}: \mathrm{e}^{-}$), are shown in Fig. 8. Most of the peaks corresponded to the well-crystalline $\mathrm{C}_{12} \mathrm{~A}_{7}$ phase (JCPDS, CAS \# 48-1882), and the existence of any second impurity phase of the $\mathrm{CaO}$ or $\mathrm{Al}_{2} \mathrm{O}_{3}$ family was not observed. With the increasing doping level, the crystallinity decreased; the samples with higher doping level, approximately more than the doping
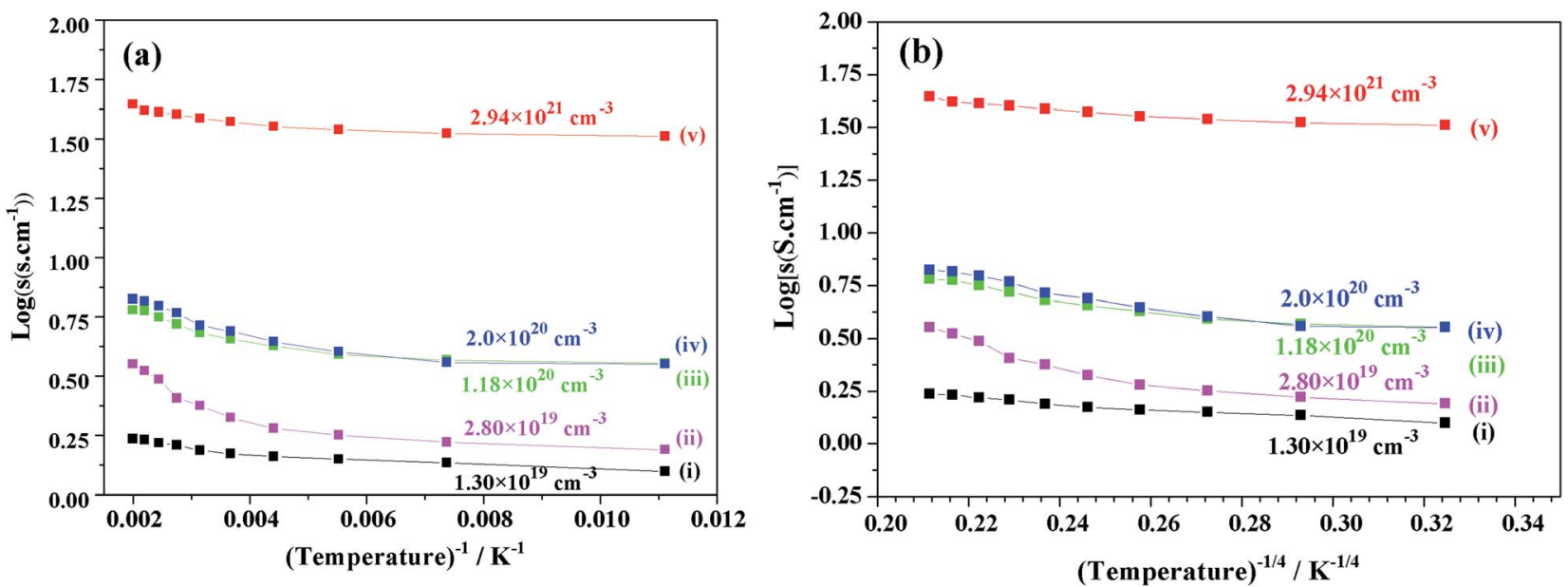

Fig. 10 Graph between $\log (\sigma)\left(\sigma\right.$, conductivity) and temperature $\left(T^{-1}, T^{-1 / 4}(K)\right)$ for $C_{12} A_{7-x} V_{x}: \mathrm{e}^{-}$samples synthesized with different $V$-doping levels, $x=$ (i) 0 , (ii) 0.25, (iii) 0.50, (iv) 0.75 and (v)1. 


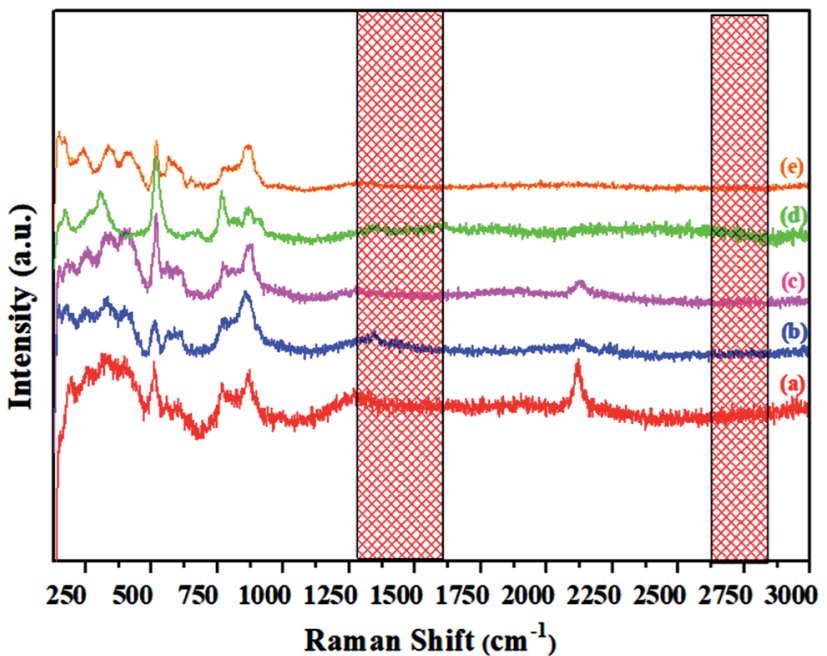

Fig. 11 Raman spectra of the molten $\mathrm{C}_{12} \mathrm{~A}_{7-x} \mathrm{~V}_{x}: \mathrm{e}^{-}$where $x=(\mathrm{a})$ $0.25 \mathrm{~V}$, (b) $0.50 \mathrm{~V}$, (c) $0.75 \mathrm{~V}$, (d) $1 \mathrm{~V}$, (e) $1.5 \mathrm{~V}$

level of $x=1.5$, showed a completely amorphous nature, with an increasing trend in conductivity.

Fig. S1 $\uparrow$ shows the SEM graph of the melted V-doped $\mathrm{C}_{12} \mathrm{~A}_{7}: \mathrm{e}^{-}$sample heat-treated at $1550{ }^{\circ} \mathrm{C}$ in an $\mathrm{N}_{2}$ atmosphere; a very dense surface of the sample was observed, and we also crushed it into particles for further characterizations. To further obtain more information about the distribution characteristics of the main metal elements, SEM associated with EDX techniques were used for the morphological study. Fig. 9 shows the compositional mapping obtained by EDS microanalysis conducted at the sample surface, where $\mathrm{Ca}, \mathrm{Al}, \mathrm{O}$ and $\mathrm{V}$ particles are shown by different colors on the distribution maps. Our results for the final sample very closely matched the theoretical values for the contents of $\mathrm{Ca}, \mathrm{O}, \mathrm{V}$ and Al. On the basis of the EDS mappings, we concluded that all the expected elements with probable contents were available and uniformly distributed on the surface of the final material.

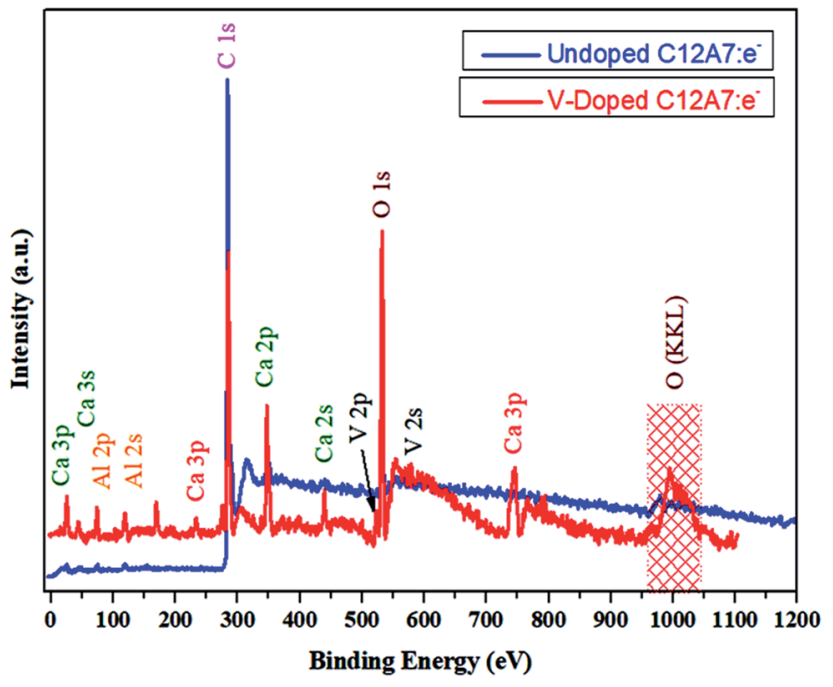

Fig. 12 XPS survey spectra of melted material.
Fig. 10 shows the plots of the $\log (\sigma) v s$. temperature $\left(\mathrm{T}^{-1}\right.$, $\mathrm{T}^{-1 / 4}(\mathrm{~K})$ ) of V-doped $\mathrm{C}_{12} \mathrm{~A}_{7}: \mathrm{e}^{-}$samples synthesized at $1550{ }^{\circ} \mathrm{C}$ for 1 hour. After doping with $\mathrm{V}$ for different doping values $(x=$ $0.25,0.50,0.75$, and 1), the conductivity increased to a maximum value of about $40 \mathrm{~S} \mathrm{~cm}^{-1}$ at $300 \mathrm{~K}$. For the highly conductive sample synthesized at $1550{ }^{\circ} \mathrm{C}, \log (\sigma)$ was almost constant, demonstrating that $\mathrm{V}$ doped- $\mathrm{C}_{12} \mathrm{~A}_{7}: \mathrm{e}^{-}$with the doping level of $x=1$ behaved like a metallic conductor. At the same time, increasing the doping level led to increase in electron concentrations with the values of $1.30 \times 10^{19} \mathrm{~cm}^{-3}, 2.80 \times 10^{19}$ $\mathrm{cm}^{-3}, 1.18 \times 10^{20} \mathrm{~cm}^{-3}$ and $2.2 \times 10^{21} \mathrm{~cm}^{-3}$.

Hence, the results showed that the increase in the conductivity of V-doped samples was because of the increase in carrier concentration, which introduced new energy states, and this was suggested by theoretical calculations based on the DFT data. ${ }^{22}$ For further studying the stability and removal of rGO in our samples after melting, we used RAMAN spectroscopy.

\section{Raman spectra of melted pristine $\mathrm{C}_{12} \mathrm{~A}_{7}: \mathrm{e}^{-}$and $\mathrm{V}$-doped} $\mathrm{C}_{12} \mathbf{A}_{7}: \mathrm{e}$

Raman spectra of the synthesized materials, shown in Fig. 11, indicate the distinct difference between the powdered electride and the molten electride. The bands at about $1340 \mathrm{~cm}^{-1}$ and $1560 \mathrm{~cm}^{-1}$ were assigned to the carbon family, which disappeared after melting; this implied that rGO was only stable in the powdered form of the crystallized $\mathrm{C}_{12} \mathrm{~A}_{7}: \mathrm{e}^{-}$, and it was released from the material during the cooling process after melting the samples. Similarly, in case of $\mathrm{V}$-doped $\mathrm{C}_{12} \mathrm{~A}_{7}: \mathrm{e}^{-}$, all of the samples showed rGO-free phase. For further elemental analysis and bonding, we studied XPS of the highly conductive $\mathrm{V}$-doped $\mathrm{C}_{12} \mathrm{~A}_{7}: \mathrm{e}^{-}$sample and compared it with the undoped sample under the same conditions.

\section{X-ray photoelectron spectroscopy (XPS)}

To further improve our understanding of cation doping and its effect on the final properties of $\mathrm{C}_{12} \mathrm{~A}_{7}: \mathrm{e}^{-}$, XPS measurements were carried out. The wide-scan XPS data of the $\mathrm{C}_{12} \mathrm{~A}_{7}: \mathrm{e}^{-}$ powders are provided in Fig. 12, and it shows the XPS core level peak spectrum of $\mathrm{C}_{12} \mathrm{~A}_{7}: \mathrm{e}^{-}$, in which $\mathrm{Ca}, \mathrm{Al}$, and $\mathrm{O}$ can be detected. The stoichiometry was confirmed to be consistent with that of $\mathrm{C}_{12} \mathrm{~A}_{7}: \mathrm{e}^{-}$, as calculated from $\mathrm{Ca} 2 \mathrm{p}, \mathrm{Al} 2 \mathrm{p}$ and $\mathrm{O} 1 \mathrm{~s}$ peak areas. Also, clear $\mathrm{V} 2 \mathrm{p}$ and $\mathrm{V} 2 \mathrm{~s}$ peaks were present in the $\mathrm{V}$ doped $\mathrm{C}_{12} \mathrm{~A}_{7}: \mathrm{e}^{-}$powder sample.

For further confirmation, the XPS spectra of individual elements, i.e., $\mathrm{Ca} 2 \mathrm{p}, \mathrm{Al} 2 \mathrm{p}, \mathrm{O} 1 \mathrm{~s}$ and $\mathrm{C} 1 \mathrm{~s}$ were obtained (Fig. 13). The Ca 2p narrow XPS spectrum (Fig. 13 (a)) had two peaks at around $352.197 \mathrm{eV}$ and $348.544 \mathrm{eV}$, which were related to Ca $2 \mathrm{p}_{1 / 2}$ and $\mathrm{Ca} 2 \mathrm{p}_{3 / 2}$, respectively. Due to spin orbit splitting, Ca 2p XPS spectrum exhibited two clearly distinguishable peaks. The narrow and sharp peaks indicated that $\mathrm{Ca}$ was connected to O. $^{41}$ The Al 2p XPS spectra in Fig. 13(b) exhibited peak positions at around $75.473 \mathrm{eV}$, which indicated that the valence state of $\mathrm{Al}$ in $\mathrm{C}_{12} \mathrm{~A}_{7}$ is the same as that of $\mathrm{Al}_{2} \mathrm{O}_{3}$. Thus, we can conclude that only $\mathrm{Ca}-\mathrm{O}$ bonds and $\mathrm{Al}-\mathrm{O}$ bonds exist in $\mathrm{C}_{12} \mathrm{~A}_{7}: \mathrm{e}^{-}$. The $\mathrm{O}$ 1s spectrum in Fig. 13(c) can be clearly deconvoluted into two distinct contributions, with peaks at 

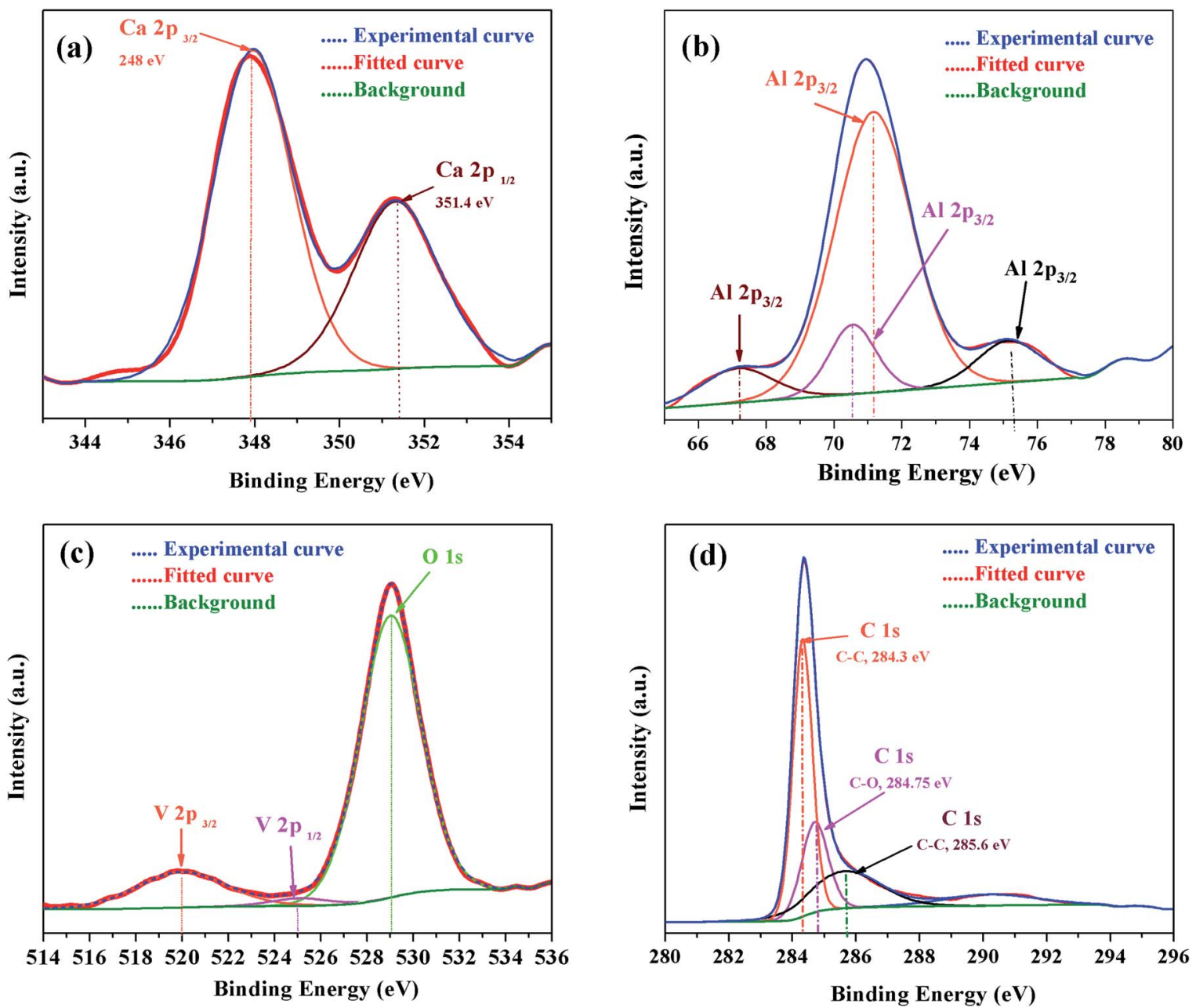

Fig. 13 XPS survey spectra of $V$-doped $C_{12} A_{7}: e^{-}$, (a) $C a 2 p$, (b) Al $2 p$, (c) $\vee 2 p \& O 1 s$ and (d) $C 1$ s.

around $531.99 \mathrm{eV}$ and $533.421 \mathrm{eV}$. The high energy component was assigned to bridging oxygen (BO) atoms, whereas the low energy component was assigned to non-bridging oxygen (NBO) atoms. ${ }^{41}$ Small peaks of $\mathrm{V} 2 \mathrm{p}_{3 / 2}$ and $\mathrm{V} 2 \mathrm{p}_{1 / 2}$ were also clearly observed. Hence, the V-doping in $\mathrm{C}_{12} \mathrm{~A}_{7}: \mathrm{e}^{-}$was clearly observed. Hence, it is clear from all these XPS results that the reduction process does not decompose the $\mathrm{C}_{12} \mathrm{~A}_{7}: \mathrm{e}^{-}$phase into other $\mathrm{CaO}$ and $\mathrm{Al}_{2} \mathrm{O}_{3}$ phases; for the first time, we have successfully developed a technique that is suitable for the synthesis of pristine as well as cation-doped $\mathrm{C}_{12} \mathrm{~A}_{7}: \mathrm{e}^{-}$.

\section{Conclusion}

Herein, we presented a general strategy and provided the first demonstration of straightforward synthesis of novel nanocrystalline $\mathrm{C}_{12} \mathrm{~A}_{7}: \mathrm{e}^{-}$without the limitations of type, shape, and size and without the formation of byproducts on the surface of the final $\mathrm{C}_{12} \mathrm{~A}_{7}: \mathrm{e}^{-}$samples, which can stop the reduction process; we used low-cost precursors, namely, $\mathrm{Ca}\left(\mathrm{NO}_{3}\right)_{2} \cdot 4 \mathrm{H}_{2} \mathrm{O}$ and $\mathrm{Al}\left(\mathrm{NO}_{3}\right)_{3} \cdot 9 \mathrm{H}_{2} \mathrm{O}$, and we also employed a very simple, cheap, and optimized sol-gel method. Stable phase of mayenite electride is acheived, which is because of the $\mathrm{C}_{2}{ }^{2-}$ template anions instead of $\mathrm{O}^{2-}$ anions in inert gas atmosphere at such a high temperature, which also contributed to the reduction process. For the first time, we successfully applied this method for the rapid synthesis of nanosized $\mathrm{C}_{12} \mathrm{~A}_{7}: \mathrm{e}^{-}$composite, pristine $\mathrm{C}_{12} \mathrm{~A}_{7}: \mathrm{e}^{-}$electride, and $\mathrm{Si}$ as well as $\mathrm{V}$-doped $\mathrm{C}_{12} \mathrm{~A}_{7}: \mathrm{e}^{-}$. The maximum specific surface area value of the $\mathrm{C}_{12} \mathrm{~A}_{7}: \mathrm{e}^{-}$composites was about 20 $\mathrm{m}^{2} \mathrm{~g}^{-1}$, with maximum electrical conductivity of about $1.25 \mathrm{~S} \mathrm{~cm}^{-1}$ and electron concentration of $5.5 \times 10^{19} \mathrm{~cm}^{-3}$. Consequently, the electrical conductivity was further improved to a maximum value of $40 \mathrm{~S} \mathrm{~cm}^{-1}$ by V-doping, with electron concentration of $2.2 \times 10^{21} \mathrm{~cm}^{-3}$. Nevertheless, the composite, pure, and doped $\mathrm{C}_{12} \mathrm{~A}_{7}: \mathrm{e}^{-}$electride samples exhibited good electrical properties, and the formation of reduced graphene in such a process without using the normally used graphene sources may be beneficial in related fields for the fabrication of highly crystalline rGO having fewer defects. ${ }^{33,42,43}$

\section{Conflicts of interest}

The authors declare no conflict of interest. 


\section{Acknowledgements}

Financial supports from Natural Science Foundation of China (NSFC) (Grant No.: 61275043, 61307048, and 61171006).

\section{References}

1 J. Huang, L. Valenzano and G. Sant, Framework and Channel Modifications in Mayenite $\left(12 \mathrm{CaO} \bullet 7 \mathrm{Al}_{2} \mathrm{O}_{3}\right)$ Nanocages By Cationic Doping, Chem. Mater., 2015, 27, 4731-4741.

2 K. Hayashi, S. Matsuishi, T. Kamiya, M. Hirano and H. Hosono, Light-induced conversion of an insulating refractory oxide into a persistent electronic conductor, Nature, 2002, 419, 462-465.

3 M. Lacerda, J. T. S. Irvine, F. P. Glasser and A. R. West, High oxide ion conductivity in $\mathrm{Ca}_{12} \mathrm{Al}_{14} \mathrm{O}_{33}$, Nature, 1988, 332, 525526.

4 S. G. Ebbinghaus, H. Krause and F. Syrowatka, Floating Zone Growth of Large and Defect-free $\mathrm{Ca}_{12} \mathrm{Al}_{14} \mathrm{O}_{33}$ Single Crystals, J. Am. Chem. Soc, 2013, 13, 2990-2994.

5 L. Palacios, A. G. D. L. Torre, S. Bruque, Ga-M. oz JL, S. G. áGranda, D. Sheptyakov, et al., Crystal Structures and in-Situ Formation Study of Mayenite Electrides, Inorg. Chem., 2007, 46(10), 4167-4176.

6 P. V. Sushko, A. L. Shluger, M. Hirano and H. Hosono, From Insulator to Electride: A Theoretical Model of Nanoporous Oxide 12CaO.7 $\mathrm{Al}_{2} \mathrm{O}_{3}$, J. Am. Chem. Soc, 2007, 129, 942-951.

7 S. W. Kim, T. Shimoyama and H. Hosono, Solvated Electrons in High-Temperature Melts and Glasses of the RoomTemperature Stable Electride $\left[\mathrm{Ca}_{24} \mathrm{Al}_{28} \mathrm{O}_{64}\right]^{4+} 4 \mathrm{e}^{-}$, Science, 2011, 333, 71-74.

8 Y. Toda, H. Hirayama, N. Kuganathan, A. Torrisi, P. V. Sushko and H. Hosono, Activation and splitting of carbon dioxide on the surface of an inorganic electride material, Nat. Commun., 2013, 1-8.

9 Y. Inoue, M. Kitano, S.-W. Kim, T. Yokoyama, M. Hara and H. Hosono, Highly Dispersed $\mathrm{Ru}$ on Electride $\left[\mathrm{Ca}_{24} \mathrm{Al}_{28} \mathrm{O}_{64}\right]^{4+}\left(\mathrm{e}^{-}\right)_{4}$ as a Catalyst for Ammonia Synthesis, ACS Catal., 2014, 4, 674-680.

10 M. Kitano, Y. Inoue, Y. Yamazaki, F. Hayashi, S. Kanbara, S. Matsuishi, et al., Ammonia synthesis using a stable electride as an electron donor and reversible hydrogen store, Nat. Chem., 2012, 4, 934-940.

11 K. Honkala, A. Hellman, I. N. Remediakis, A. Logadottir, A. Carlsson, S. Dahl, et al., Ammonia Synthesis from FirstPrinciples Calculations, Science, 2005, 307, 555-558.

12 M. Lacerda, J. T. S. Irvine, F. P. Glasser and A. R. West, High oxide ion conductivity in $\mathrm{Ca}_{12} \mathrm{Al}_{14} \mathrm{O}_{33}$, Nature, 1988, 332, 525-526.

13 M. Lacerda, J. T. S. Irvine, F. P. Glasser and A. R. West, High oxide ion conductivity in $\mathrm{Ca}_{12} \mathrm{Al}_{14} \mathrm{O}_{33}$, Nature, 1988, 332(7), 525-526.

14 H. Hosono, K. Hayashi, K. Kajihara, P. V. Sushko and A. L. Shluger, Oxygen ion conduction in $12 \mathrm{CaO} \cdot 7 \mathrm{Al}_{2} \mathrm{O}_{3}: \mathrm{O}^{2-}$ conduction mechanism and possibility of $\mathrm{O}^{-}$fast conduction, Solid State Ionics, 2009, 180, 550-555.
15 K. Hayashi, S. Matsuishi, T. Kamiya, M. Hirano and H. Hosono, Light-induced conversion of an insulating refractory oxide into a persistent electronic conductor, Nature, 2002, 419, 462-465.

16 H. Buchammagari, Y. Toda, M. Hirano, H. Hosono, D. Takeuchi and K. Osakada, Room Temperature-Stable Electride as a Synthetic Organic Reagent: Application to Pinacol Coupling Reaction in Aqueous Media, Org. Lett., 2007, 9(21), 4287-4289.

17 Z. Wang, Y. Pan, T. Dong, X. Zhu, T. Kan, L. Yuan, et al., Production of hydrogen from catalytic steam reforming of bio-oil using C12A7.O- based catalysts, Appl. Catal., A, 2007, 320, 24-34.

18 S. Watanabe, T. Watanabe, K. Ito, N. Miyakawa, S. Ito, H. Hosono, et al., Secondary electron emission and glow discharge properties of $12 \mathrm{CaO} \cdot 7 \mathrm{Al}_{2} \mathrm{O}_{3}$ electride for fluorescent lamp applications, Sci. Technol. Adv. Mater., 2011, 12, 1-8.

19 Y. Nishioa, K. Nomurab, H. Yanagi, T. Kamiyaa, M. Hiranob and $\mathrm{H}$. Hosono, Short-channel nanowire transistor using a nanoporous crystal semiconductor $12 \mathrm{CaO} \cdot 7 \mathrm{Al}_{2} \mathrm{O}_{3}, J$. Mater. Sci. Eng. B, 2010, 173, 37-40.

20 Y. Toda, Y. Kubota, M. Hirano, H. Hirayama and H. Hosono, Surface of Room-Temperature-Stable Electride $\left[\mathrm{Ca}_{24} \mathrm{Al}_{28} \mathrm{O}_{64}\right]^{4+}\left(\mathrm{e}^{-}\right)_{4}$ : Preparation and Its Characterization by Atomic-Resolution Scanning Tunneling Microscopy, ACS Nano, 2011, 5(3), 1907-1914.

21 F. Hayashi, M. Kitano, T. Yokoyama, M. Hara and H. Hosono, Surface Treatment for Conductive $12 \mathrm{CaO} \cdot 7 \mathrm{Al}_{2} \mathrm{O}_{3}$ Electride Powder by Rapid Thermal Annealing Processing and Its Application to Ammonia Synthesis, ChemCatChem, 2014, 6, 1317-1323.

22 J. Huang, L. Valenzano and G. Sant, Framework and Channel Modifications in Mayenite $\left(12 \mathrm{CaO} \cdot 7 \mathrm{Al}_{2} \mathrm{O}_{3}\right)$ Nanocages By Cationic Doping, Chem. Mater., 2015, 27, 4731-4741.

23 M. MIBaTO, Enhanced electronic conductivity in Sisubstituted calcium aluminate, J. Appl. Phys., 2007, 102, 113704-1-113704-7.

24 Y. Dong, K. Hayashi, H. Nozoe, Y. Shinoda and H. Hosono, Chloride-Ion-Stabilized Strontium Mayenite: Expansion of Versatile Material Family, J. Am. Ceram. Soc., 2014, 97(12), 4037-4044.

25 J. Li, Y. Pan, F. Qiu, Y. Wu and J. Guo, Nanostructured Nd:YAG powders via gel combustion: The influence of citrate-to-nitrate ratio, Ceram. Int., 2008, 34, 141-149.

26 C. Li, D. Hirabayashi and K. Suzuki, Synthesis of higher surface area mayenite by hydrothermal method, Mater. Res. Bull., 2011, 46, 1307-1310.

27 S. N. Ude, C. J. Rawna, R. A. Peascoe, M. J. Kirkhamc, G. L. Jones and E. A. Payzant, High temperature X-ray studies of mayenite synthesized using the citrate sol-gel method, Ceram. Int., 2014, 40, 1117-1123.

28 Y. Matsuyam, M. Hori, N. Wakiya and H. Suzuki, Solution derived $12 \mathrm{CaO} \cdot 7 \mathrm{Al}_{2} \mathrm{O}_{3}$ thin films on $\mathrm{MgO}\left(\begin{array}{lll}1 & 0 & 0\end{array}\right)$ substrate, J. Mater. Sci. Eng. B, 2010, 173, 21-24. 
$29 \mathrm{~S}$. W. Kim and H. Hosono, Synthesis and properties of $12 \mathrm{CaO} .7 \mathrm{Al}_{2} \mathrm{O}_{3}$ electride: review of single crystal and thin film growth, Philos. Mag., 2012, 92(19-21), 2596-2628.

30 W. Zou, K. Khan, X. Zhao, C. Zhu, J. Huang, J. Li, et al., Direct Fabrication of C12A7 Electride Target and Room Temperature Deposition of Thin Films with Low Work Function, Mater. Res. Express, 2017, 4(3), 1-20.

31 W. Dai, J. Yu, Y. Wang, Y. Song, F. E. Alam, K. Nishimura, et al., Enhanced thermal conductivity for polyimide composites with a three-dimensional silicon carbide nanowire@graphene sheets filler, J. Mater. Chem. A, 2015, 3, 4884-4891.

32 K. Khan, A. K. Tareen, S. Elshahat, A. Yadav, U. Khan, M. Yang, et al., Facile synthesis of cationic doped $\left[\mathrm{Ca}_{24} \mathrm{Al}_{28} \mathrm{O}_{64}\right]^{4+}$. $\left(4 \mathrm{e}^{-}\right)$composite via rapid citrate sol-gel method, Dalton Trans., 2018, 47, 3819-3830.

33 K. S. Kim, Y. Zhao, H. Jang, S. Y. Lee, J. M. Kim, K. S. Kim, et al., Large-scale pattern growth of graphene films for stretchable transparent electrodes, Nature, 2009, 457, 706710.

34 C.-T. Lin, W.-C. Chen, M.-Y. Yen, L.-S. Wang, C.-Y. Lee, T.-S. Chin, et al., Cone-stacked carbon nanofibers with cone angle increasing along the longitudinal axis, Carbon, 2007, 45, 411-415.

35 Y. Xue, B. Wu, L. Jiang, Y. Guo, L. Huang, J. Chen, et al., Low Temperature Growth of Highly Nitrogen-Doped Single Crystal Graphene Arrays by Chemical Vapor Deposition, J. Am. Chem. Soc, 2012, 134, 11060-11063.
36 A. C. Ferrari, J. C. Meyer, V. Scardaci, C. Casiraghi, M. Lazzeri, F. Mauri, et al., Raman Spectrum of Graphene and Graphene Layers, Phys. Rev. Lett., 2006, 97, 187401.

37 Y. Yin, Z. Jia, W. Mu, Z. Gao, J. Zhang and X. Tao, Mechanism of Surface Cracking in a $\mathrm{Ca}_{12} \mathrm{Al}_{14} \mathrm{O}_{33}$ Crystal during the Cooling Process, Cryst. Growth Des., 2016, 1903-1906.

38 Y. Dong, H. Hosono and K. Hayashi, Formation and quantification of peroxide anions in nanocages of 12CaO.7 $\mathrm{Al}_{2} \mathrm{O}_{3}$, RSC Adv., 2013, 3, 18311-18316.

39 S. W. Kim, S. Matsuishi, T. Nomura, Y. Kubota, M. Takata, K. Hayashi, et al., Metallic State in a Lime-Alumina Compound with Nanoporous Structure, Nano Lett., 2007, 7(5), 1138-1143.

40 A. Ranjbar and M. Rezaei, Low temperature synthesis of nanocrystalline calcium aluminate compounds with surfactant-assisted precipitation method, Adv. Powder Technol., 2013, 1-5.

41 R. K. Pan, S. Feng and H. Z. Tao, XPS and NMR analysis on $12 \mathrm{CaO} \cdot 7 \mathrm{Al}_{2} \mathrm{O}_{3}$, IOP Conf Series: Materials Science and Engineering, 2017, 167, 012017.

42 H. Medina, Y.-C. Lin, C. Jin, C.-C. Lu, C.-H. Yeh, K.-P. Huang, et al., Metal-Free Growth of Nanographene on Silicon Oxides for Transparent Conducting Applications, Adv. Funct. Mater., 2012, 22, 2123-2128.

43 C. Shan, H. Tang, T. Wong, L. He and S.-T. Lee, Facile Synthesis of a Large Quantity of Graphene by Chemical Vapor Deposition: an Advanced Catalyst Carrier, Adv. Mater., 2012, 24, 2491-2495. 